\title{
SZIKINGER ISTVÁN
}

\section{Az emberi jogok és a totális hatalom}

Köztudomású ténynek tekinthető az, amit rögzít az Amnesty International 2017-2018-as jelentése is: az Emberi jogok egyetemes nyilatkozata megszületésének hetvenedik évfordulójához közeledve senki nem állíthatja, hogy az emberi jogok érvényesülését garantálták. ${ }^{1}$ Megvalósulásukért tehát állandóan dolgozni, sőt: küzdeni kell.

Kérdés persze, hogy szükséges-e ma e jogokat követelni, egyáltalában: van-e az emberiség, az egyes társadalmak, csoportok, valamint az egyének számára értékelhető hozadéka azok megvalósulásának? A Századvég Intézet 2013-as kutatása szerint a magyar emberek kilencvennyolc százaléka szerint fontos vagy nagyon fontos az emberi jogok védelme. Mindamellett a megkérdezettek jelentős része egyetlen jogot sem tudott megnevezni, amellett számos olyan válasz érkezett, amely szerint alkotmányosan nem ilyennek ismert értékek tekinthetők emberi jogoknak (például az árvák védelme, a normális élethez való jog stb.). ${ }^{2}$ Ebböl levonható az a következtetés, hogy a társadalom kimagaslóan pozitív szerepet tulajdonít az emberi jogoknak, anélkül azonban, hogy a valóságos problémákról tudomása volna.

A felmérés adatai lényegében azt az értékelést támasztják alá, amely szerint az emberi jogok inkább egyfajta mítoszt jelentenek az emberek számára, az érvényesítésükre irányuló törekvések nem egyértelmüen alkalmasak a világ jobbá tételére. Erre a következtetésre jutott például Günter Frankenberg, akinek az írására is felhívta a figyelmet a Századvég. ${ }^{3}$ Michael Ignatieff ezzel szemben - az általa hivatkozott szerzőkkel együtt - tényként érzékelte az emberi jogok szakrális jellegét, sőt: bálványimádásnak minősíthető viszonyulásunkat. Ez szerinte szoros összefüggésben áll az ideológiai háttér tisztázatlan kérdéseivel, de a különböző életszemléletet képviselő iszlám, ázsiai és európai megközelítésekkel is. Mégis úgy véli: az emberi jogok történeti és

\footnotetext{
1 Amnesty International Report 2017/18. Foreword, Amnesty International, London, 2018, p. 12.

$2 \mathrm{https}$ //szazadveg.hu/hu/kutatasok/az-alapitvany-kutatasai/elemzesek-publikaciok/kozvelemenykutatas-az-emberi-jogok-fontossagarol-es-ismertsegerol-magyarorszagon

3 Günter Frankenberg: Human Rights and the Belief in a Just World. International Journal of Constitutional Law, vol. 12, no. 1, 2014, pp. 35-60.

https://szazadveg.hu/hu/kutatasok/az-alapitvany-kutatasai/otletmuhely/az-emberi-jogok-mitosza
} 
- legföképpen - gyakorlati kezelése alkalmas arra, hogy háttérbe szorítsa a kételyeket és a hittel helyettesített tudást. ${ }^{4}$

A legsúlyosabb vádakat azok fogalmazzák meg az emberi jogokkal szemben, akik egyfajta imperializmust látnak a világméretủ terjesztésben. Konkrétan arról van szó, hogy a jogok és a mögöttük álló szemlélet egyértelmüen a nyugati civilizáció értékeit tükrözik, univerzálissá nyilvánításuk tehát óhatatlanul az egyéb kultúrák lebecsülését jelenti. Megjegyzendő, hogy az e nézetet képviselő szerzők többnyire nem utasítják el az emberi jogok rendszere kiépítésének a szükségességét, rámutatnak azonban arra, hogy azt a kölcsönös tisztelet, az egyenlőség jegyében kellene véghez vinni. ${ }^{5}$ Hangsúlyozni kell azt is, hogy az említett tendenciák a történelemben egyáltalában nem zárták ki az emberi jogokra való hivatkozást a nemzeti felszabadító - tehát antiimperialista - mozgalmak keretében. ${ }^{6}$

Az Emberi Jogok Európai Bírósága előtt folyt eljárásban az Al-Skeini és mások kontra Egyesült Királyság-ügyben a briteket elmarasztaló ítélethez Giovanni Bonello bíró párhuzamos véleményt csatolt. Ebben kitért a katonai beavatkozást végrehajtó brit kormány azon hivatkozására - saját felelőssége alóli mentesülése érdekében -, hogy az Európai emberi jogi egyezmény nem exportálható Irakba még akkor sem, ha ténylegesen a bepanaszolt állam által ellenőrzött területröl volt szó. Az érvelés szerint az ilyen alkalmazás imperializmust valósítana meg. A bíró rámutatott arra az abszurd helyzetre, amelyben a katonai támadást nem, de a jogvédelem kiterjesztését imperialistának nyilvánította a megszálló hatalom. ${ }^{7}$ Ez a példa is megerősíti, hogy nem csupán az emberi jogok, hanem még a rájuk vonatkozó értékelő vélemények is teljesen különböző politikai célokra használhatók fel. Természetesen meg kell különböztetni a jogok tartalmát, az érvényesítésük rendjét a retorikától.

Közvetlenül tehát nem a jogok lényege és tartalma, hanem azok ürügyként történő felhasználása sértheti egyes közösségek méltóságát. Ezzel együtt nem tagadható a jogoknak az európai értékekhez való kötődése, ami az említettek szerint módosítható az egyenlőség elvére építő jogalakítással. Még

4 Michael Ignatieff: I. Human Rights as Politics II. Human Rights as Idolatry. The Tanner Lectures on Human Values, Princeton University, April 4-7, 2000 https://tannerlectures.utah.edu/_documents/ato-z/i/Ignatieff_01.pdf

5 Vitus Ozoke: The Imperialism of Rights: Tracing the Politics and History of Human Rights. American International Journal of Contemporary Research, vol. 4, no. 12, 2014, pp. 1-7.

6 Lásd Ibhawoh Bonny: Imperialism and Human Rights: Colonial Discourses of Rights and Liberties in African History. State University of New York Press, Albany, 2007

7 Al-Skeini és mások kontra Egyesült Királyság, 55721/07 sz. kérelem, 2011. július 7-i ítélet. 
akkor is, ha az eredeti ideológia szerint az emberi jogok a természetből erednek, nem formálhatók önkényesen.

A valóság mégis az, hogy konkrét megjelenési formájukban - tehát a kikényszerítés lehetőségét tartalmazóan - a jogok igen jelentős változásokon mentek keresztül úgy, hogy az alapjukat képező értékek köre bővült az eredetileg oltalmazni kívánt jogi tárgyak megőrzése mellett. Az emberi jogok újabb generációinak a megjelenése, egyáltalában: a rájuk vonatkozóan végbement fejlódés alkalmassá tette azokat a legfontosabb társadalmi értékek szolgálatára a változó körülmények között, másrészt nyilvánvalóan egyre jobban megnehezítette - sőt: lényegében lehetetlenné tette - egységes elméleti megalapozásukat. Egy részük csak állampolgári jogként értelmezhetö, ami az univerzalitást természetesen kizárja. A különbségek áthidalására létrehozott ,alapjogok” kategória valójában a tárgyi jog felé mozdította el a „veleszületett és elidegeníthetetlen" jogok koncepcióját, hiszen az alapjogokat mindenekelőtt a nemzeti alkotmányok kereteihez igazítják.

Kiemelkedően fontos - és álláspontom szerint helyes - értelmezési és alkalmazási szempontot rögzített a Német Szövetségi Alkotmánybíróság, amikor kinyilvánította: a [német] alaptörvény emberképe nem egy elszigetelt és öntörvényü egyént jelenít meg. Sokkal inkább arról van szó, hogy az ember és a közösség közötti feszültség viszonyai között kell szemlélni az elöbbiek helyzetét a társadalmi meghatározottság keretében azzal együtt, hogy a személyiség saját értékét tiszteletben kell tartani. ${ }^{8}$

A másik jelentős fejlemény az, hogy az eredetileg határozottan érvényesíteni kívánt közhatalom-magánszféra, ennek megfelelően a közjog-magánjog különbségtétel a történelmi fejlődés során relativizálódott, ha meg nem szünt is. Az mindenesetre tény, hogy melyek azok az értékek, amelyeket az alapító atyák a közhatalom zsarnokságával szemben kívántak védelmezni. Az Ember és Polgár Jogainak Nyilatkozata (1789) például garanciaként rögzítette, hogy a közigazgatás tisztviselőinek felelősségre vonása, a törvényhozás és a végrehajtás szétválasztása elengedhetetlen az alkotmányosság megvalósulásához (15-16. pont).

Az intézményrendszer differenciálódása és a többoldalú kiszolgáltatottság növekedése miatt az emberek egyre inkább veszélybe kerültek az államtól és a helyi önkormányzatoktól független tényezők miatt. A jogok értékeket védenek, azok megsértése pedig nem maradhat válasz nélkül akkor sem, ha nem közvetlenül a közhatalom részéröl történt. A Német Szövetségi Alkotmány-

8 BVerfGE 4, 7 - Investitionshilfe. 
bíróság a Lüth-itéletben ${ }^{9}$ mondta ki, hogy az alapjogoknak közvetve a magánjogban is érvényesülniük kell.

Hazánkban a polgári törvénykönyvről szóló 2014. évi V. törvény 1:2. §ának (1) bekezdése tartalmazza, hogy a rendelkezéseket Magyarország alkotmányos rendjével összhangban kell értelmezni. Az egyenlő bánásmódról és az esélyegyenlőség előmozdításáról szóló 2003. évi CXXV. törvény 4. §-a úgy rendelkezik, hogy az egyenlő bánásmód - nyilvánvalóan alkotmányos, illetőleg alaptörvényi - kötelezettsége a közhatalom intézményei mellett kiterjed a közalapítványokra, köztestületekre, a munkavállalók és munkáltatók érdekképviseleti szervezeteire, a közszolgáltatást végző szervezetekre, a közés felsőoktatási, a gyermekekkel foglalkozó, a közmüvelődési intézményekre, a magánnyugdíjpénztárakra, az egészségügyi szolgáltatókra, a pártokra, valamint más költségvetési szervekre.

Megállapítható tehát, hogy az emberi jogok (alapjogok) tiszteletben tartására és érvényre juttatásuk feltételeinek szavatolására vonatkozó kötelesség a jogok eredeti rendeltetésének megfelelően elsődlegesen a közhatalmat terheli, a mögöttes értékek védelme céljából azonban az közvetve, de korlátozott körben közvetlenül is kiterjed a magánjog alanyaira.

A jelzett problémák ellenére azt lehet mondani, hogy az emberi jogok körét illetően alapvetően világméretủ egyetértés van, hiszen az azokat tételesen tartalmazó két dokumentumot (a Polgári és politikai jogok nemzetközi egyezségokmányát, valamint a Gazdasági, szociális és kulturális jogok nemzetközi egyezségokmányát) a Föld országainak többsége elfogadta (az előbbinek 171, az utóbbinak 168 részes állama van) ${ }^{10}$. A továbbiakban tehát eltérő utalás hiányában az e szerződésekben rögzített emberi jogok érvényesülésének egyes kérdéseit vizsgálom.

\section{Az emberi jogok és a demokrácia}

Az alcímben említett kétfajta értékrend természetesen nem mosható össze. Azok egymást sok tekintetben feltételezik (például a választójog révén), mindazonáltal bizonyos viszonyok közepette akár ellentétbe is kerülhetnek egymással. ${ }^{11}$

9 BVerfGE 7, $198 \mathrm{ff}$.

10 Forrás: United Nations Treaty Collection.

11 Lásd például Jürgen Habermas: Faktizität und Geltung - Beiträge zur Diskurstheorie des Rechts und des Demokratischen Rechtstaats. Suhrkamp Verlag, Frankfurt am Main, 1992. 
A kölcsönös függés azt is jelenti, hogy a két elvárásrendszer bármelyikének jelentős sérelme kihat a másikra.

A demokráciával a diktatúrát szokás szembeállítani. A totális hatalom azonban még tovább megy: teljes kontrollt kíván gyakorolni a társadalom tagjai felett. Az állam és a társadalom különválasztása lényegében megszünik ${ }^{12}$, ebből okszerüen következik, hogy valóban eltünik a két szféra elkülönülését is kifejező emberi jogok rendszere. Mindebből logikusan adódik a következtetés: a jogok védelme, megvalósulásuk garanciái a totális hatalom kiépülésével szemben is fékező hatást gyakorolnak.

Nem cáfolható a totális rendszerek kiemelkedő kutatójának, Hannah Arendtnek a jogokra és a hatalomgyakorlás jellegére vonatkozó megállapítása: „Az örült végeredményhez - a koncentrációs táborok társadalmához - képest áttekinthetö és logikus az a folyamat, amelynek során az embereket felkészitik erre a célra, valamint azok a módszerek, amelyekkel hozzászoktatják öket ezekhez a körülményekhez. A holttetemek eszeveszett tömegtermelését az élöhalottak történelmileg és politikailag érthetö elökészitése elözi meg. [...] Ez [...] csak azért következhetett be, mert az emberi jogok, amelyeket filozófiailag sohasem alapoztak meg, csupán megfogalmaztak, amelyeket politikailag sohasem garantáltak, csupán meghirdettek, hagyományos formájukban minden érvényüket elvesztették. "'13

A huszadik század borzalmaihoz vezető folyamatok utólag valóban rekonstruálhatók. Az emberi jogok leépítése a hatalmi célok szolgálatában katasztrófákhoz vezetett. Logikus a következtetés: az emberi jogok érvényesülésének a garantálása akadályát képezi a totális rendszerek kialakulásának, hiszen az utóbbiakat éppen az jellemzi, hogy a hatalom akaratával szemben nincs olyan eszköz és erő, amely a tombolást akár csak fékezhetné.

A veszély nem múlt el. Ahogyan azt Timothy Snyder is meggyőzően bizonyítja, a totális rendszerek visszatérésének fenyegetése nagyon is aktuális mind Amerikában, mind pedig Európában. ${ }^{14}$

Azt is meg kell jegyezni, hogy a totális hatalom soha, sehol nem valósult meg teljes mértékben, hiszen a mögötte álló szándék - a társadalom teljes kontrollja - irreális. A pusztítás viszont - ahogyan a történelem azt példázza -

\footnotetext{
12 Carl Schmittre hivatkozva Bihari Mihály: Politológia. A politika és a modern állam. Pártok és ideológiák. Nemzedékek Tudása Tankönyvkiadó Zrt., Budapest, 2013 https://www.tankonyvtar.hu/hu/tartalom/tamop425/2011_0001_519_40137/adatok.htm 13 Hannah Arendt: A totalitarizmus gyökerei. Európa Kiadó, Budapest, 1992, 333. o.

14 Timothy Snyder: Bloodlands: Europe Between Hitler and Stalin. Basic Books, New York, 2010; Timothy Snyder: Húsz lecke a zsarnokságról. 21. Század Kiadó, Budapest, 2017; Timothy Snyder: The Road to Unfreedom. Duggan Books, London, 2018
} 
így is elviselhetetlen. Azzal is egyet lehet érteni, hogy az ilyen rendszerek egymástól is különböznek, a jelen kor veszélyei nem abban állnak, hogy pontosan ugyanolyan modellek alakulnak ki, mint a huszadik században. ${ }^{15}$ Valójában az a kérdés, hogy sikerül-e a hatalomnak olyan módon maga alá gyürnie az embereket, ami már nem teszi lehetővé számukra az önálló - vagy másokkal együtt kialakított és érvényesített - politikai akarat érdemi kifejezését, egyáltalában: a személyiség szabad kibontakoztatását és az államtól független kollektív cselekvést.

A mondottak alapján egyértelmủen leszögezhetö, hogy az emberi jogok érvényesülése és tartós garantáltságuk mellett nincs esélyük a totális hatalmi törekvéseknek. Hangsúlyozni kell persze, hogy nem konkrét politikai mozgásokról van szó a jelen írásban, azonban a lehetőségek a történelem tanulságai szerint vonzzák a kihasználásukra képes és arra törekvő erőket. Másrészt az a kérdés is okkal és joggal vethető fel, hogy mi lehet az okuk az alkotmányban és az alaptörvényben is rögzített elsőrendủ állami kötelezettség teljesítésében mutatkozó hiányosságoknak.

\section{Az emberi jogok helyzetének alakulása Magyarországon a rendszerváltás óta}

Meglepő javaslattal állt elő az ENSZ-nek az emberi jogi aktivisták és csoportok helyzetével foglalkozó különmegbízottja a 2016 februárjában, Magyarországon tett látogatása után: egyebek mellett azt kérte, hogy a kormányzat ,,... foglalja bele az emberi jogokat az intézményi és szakpolitikai keretrendszerbe, többek között egy világos és konkrét célkitüzéseket és mutatókat tartalmazó, az emberi jogokra vonatkozó nemzeti cselekvési terv elfogadásával, figyelembe véve a nemzetközi és az európai emberi jogi mechanizmusok ajánlásait is "'16. A jelentés egészét olvasva nyilvánvalóvá válik, hogy a megbízott, Michel Forst nem azért állt elő ezzel a kezdeményezéssel, mert nem ismeri az alaptörvény I. cikkének (1) bekezdését, amely kimondja, hogy az emberi jogok védelme az állam elsőrendű kötelezettsége. Sokkal inkább arról van szó, hogy a jelentéstevő nem tapasztalta ennek a meghatározó jelentőségü követelménynek a tényleges közhatalmi gyakorlatban való érvényesülését.

Tételem az, hogy hazánkban hiányzik az a kultúra, amely a jogok demokráciavédelmi funkcióját megalapozhatná. Ez a szocializmus viszonyai között

15 Slavoj Zizek: Did Someone say Totalitarianism? Verso, London-New York, 2001

$16 \mathrm{https}$ ://www.ohchr.org/EN/NewsEvents/Pages/DisplayNews.aspx?NewsID=17048\&LangID=E 
érthető, azonban - ahogyan jelezni fogom - a rendszerváltozás óta sincs elörehaladás a modern állam kialakulása és müködése szempontjából kiemelkedően fontos követelményrendszer megértésében. Ezt a következetést néhány - különböző politikai meghatározottságú kormánytöbbség időszakaiból való - példával kívánom alátámasztani.

A rendőrségről szóló törvényjavaslat vitája

Nem elsősorban arról van szó, hogy a kormányzás és a törvényhozás valamilyen magasabb szempontra (vagy időleges veszélyre) hivatkozva háttérbe szorítaná az emberi szabadságot és a többi alaptörvényi értéket. Sajnos nagyon sok esetben a probléma sem vetődik fel. Egyes jogkorlátozó döntések úgy születnek meg, hogy róluk még érdemi vitát sem folytatnak. A hatalom tényezői pedig enyhén szólva is sajátosan értelmezik az emberi jogokat. Boross Péter belügyminiszterként a rendőrségi törvény 1993-as országgyülési vitája során a következőket mondta: „Az állampolgárok biztonságát a demokratikus berendezkedésü államok alapvetö emberi jogként ismerik el. Az állam feladata ennek a jognak a szavatolása. A hazai közfelfogásban az emberi jogok érvényesülésének területe az állampolgár és a hatóság viszonyára korlátozódott és szükült le. Kevesebb szó esik arról, hogy a polgárt megilletö alapvetö emberi jogokat a többi polgár is köteles tiszteletben tartani, $s$ az állam azt szavatolja, hogy a jogok megsértése esetén az azokat tiszteletben tartó állampolgárt a törvény elöirásai szerint védelemben részesiti. [...] A rendörség tehát olyan hatóság, amely a törvényekben meghatározott módon és eszközökkel segíti, védi, oltalmazza az emberi jogokat. A rendörség a jogsértó állampolgár ellen jár el, nyugton hagyja a jog szerint cselekvöt."

Az emberi jogok és a közhatalom viszonyának ez az értelmezése teljes mértékben téves. Ugyanakkor - amint látni fogjuk - mindmáig nem sikerült cáfolni, a szemlélet továbbra is hat, jelentős mértékben befolyásolja a jogalkotást és a jogalkalmazást.

Kiemelendő mindenekelőtt, hogy az állampolgárok (emberek) biztonsága mint alapjog egyáltalában nem azonosítható a rendőrség által oltalmazott közbiztonsággal, még annak az egyénekre vetítésével sem. A Polgári és politikai jogok nemzetközi egyezségokmányának 9. cikke például ezzel kapcsolatban a következöket tartalmazza: „,Mindenkinek joga van a szabadságra és a személyi biztonságra. Senkit sem lehet önkényesen örizetbe venni vagy le-

17 Boross Péter expozéja a rendörségről szóló törvény javaslatának vitáján, 1993. október 5-én. 
tartóztatni. Senkit sem lehet szabadságától másként, mint a törvényben meghatározott okokból és a törvényben meghatározott eljárás alapján megfosztani." A biztonság emberi jogként tehát elsődlegesen a hatalom önkényével szembeni védettséget jelenti. Az állam az önkormányzatokkal együtt valóban köteles ugyan mindent megtenni a jogsértések megakadályozása, illetőleg szankcionálása érdekében, de senkinek nincs alanyi joga arra, hogy ezt kikényszerítse a saját személyes és vagyoni értékeinek megóvása céljából. Voltak ugyan kísérletek az emberek jelzett értelemben vett biztonsághoz való alapjoga létezésének a bizonyítására, ezek azonban nem tudtak intézményesedni. ${ }^{18}$

A német Bundestag figyelmet érdemlőnek ítélte a teóriát, és tanulmányt készíttetett a kérdésről. Az anyag ${ }^{19}$ lényegében ugyanerre a következtetésre jut: az állam fontos feladata a biztonságról való gondoskodás, ez azonban nem fogható fel valamiféle emberi vagy állampolgári jog garanciájaként. Megemlítette viszont a szerző (akit - vagy akiket - anonimizáltak a közzétett dokumentumban), hogy a biztonsághoz való alapjog koncepciójához kapcsolódóan dolgozta ki Günther Jakobs az ellenség-büntetőjog tanát, ami szerint a demokratikus társadalmi rendet fenyegető terroristákat meg kell fosztani az emberi jogok élvezetétől, öket nem lehet személyként kezelni. ${ }^{20}$

Ez a példa is mutatja, hogy az emberi jogok félreértelmezése milyen könynyen és gyorsan elvezet azok teljes tagadásához, a „terrorista” címke helyenként igen kiterjesztő módon való ragasztgatása mellett pedig akár a totális hatalomhoz. Ha egyes embereket - különösen csoportokat - megfosztanak az emberi jogok élvezetétől, akkor az egész intézmény értelmét és funkcióját veszti, hiszen annak éppen az az alapja, hogy minden embert megilletnek ezek az értékek. A hiányuk megnyitja az utat a korlátlan hatalomhoz. Ez a mondanivalója Hannah Arendt már hivatkozott müvének is, amit egyébként a történelem teljes mértékben igazolt.

Az idézett parlamenti bevezető szerint az alapvető jogokat a többi polgár is köteles tiszteletben tartani. Az emberi jogoknak a civil társadalmon belüli szerepéröl már volt szó. Arról is, hogy egyfajta közvetett hatásról beszélhe-

\footnotetext{
18 Josef Isensee: Das Grundrecht auf Sicherheit, Schriftenreihe der Juristischen Gesellschaft zu Berlin, Bd. 79. Berlin, 1982

19 Zum „Grundrecht auf Sicherheit“. Deutsche Bundestag, Berlin, 2008. https://www.bundestag.de/blob/423604/6bc141a9713732fc4bb4334b6d02693b/wd-3-180-08-pdfdata.pdf

20 Günther Jakobs: Bürgerstrafrecht und Feindstrafrecht, Onlinezeitschrift für Höchstrichterliche Rechtsprechung zum Strafrecht, 2004.

https://www.hrr-strafrecht.de/hrr/archiv/04-03/index.php3? seite=6
} 
tünk. A mögöttes értékek (élet, tulajdon stb.) védelme természetesen jelen van az egész jogrendszerben, de azok oltalmazása túlnyomórészt nem az emberi jogok érvényesítésére létrejött intézmények feladata. Senki nem fordulhat eredményesen az alapjogi biztoshoz vagy az Alkotmánybírósághoz azért, mert a szomszédja felpofozta.

Az emberi jogok védelmének hivatkozott felfogása azt a veszélyt hordozza, hogy elterelödik a figyelem az intézmény eredeti és elsődleges funkciójáról: a hatalomnak való kiszolgáltatottsággal szembeni védelemről. Valójában ezt nyomatékosította a rendőrségi törvény javaslatának előadója akkor, amikor kijelentette: „A rendörség a jogsértö állampolgár ellen jár el, nyugton hagyja a jog szerint cselekvöt." Ez jól hangzik, de nem igaz. A rendőri cselekvés ugyanis döntö többségében nem törvényszegésekre reagál, hanem veszélyeket kíván elhárítani. A jogsértőkkel szembeni eljárás egy demokratikus jogállamban sokkal inkább a bíróságokra és más szervekre (például büntetésvégrehajtás) hárul. A decens polgárok békében hagyása sem tükrözi a valóságot, hiszen ma például a gyanú esetleges fennállásának a megállapítása érdekében is leplezett eszközöket (például lehallgatás) lehet alkalmazni (Be. 339. és köv. §-ok). Megjegyzendő, hogy ez lényegét tekintve már a rendőrségi törvény 1994-es elfogadásától így volt, hiszen a jogszabály 63. § (1) bekezdése kimondta: titkos információgyüjtés büncselekmény megelözése céljából is alkalmazható.

Megjegyzendő, hogy a közbiztonság védelmére rendelt szervezet ítélőképességére, tévedhetetlenségére utaló mondat tükröződött is a törvényben, hiszen a jogalkotó szerint a rendőrség által általában ellátott rendészeti tevékenység az indokolás szerint semmilyen jogágba nem sorolható, ennélfogva ilyen módon meghatározott kontrollt (például közigazgatási bíráskodás) sem lehetett gyakorolni az intézkedések saját hatáskörben való elbírálása felett (panaszeljárás). A Legfelsőbb Bíróságnak kellett kimondania azt a magától értődő tételt, hogy a rendőri tevékenység zömmel a közigazgatás körébe tartozik. ${ }^{21}$

Sóvágó László, a kormánykoalíciót vezető MDF vezérszónoka egyenesen kijelentette: más megoldások mellett a titkos módszerek szabályozása erősíti a jogbiztonságot, bár felvetődik az emberi jogok sérelme. A képviselő szerint azonban a külön engedélyhez nem kötött eszközök esetében ,, ... nagyobb érdek füzödik ezek engedély nélküli gyakorlásához, mint az esetleges jogsértések kiküszöböléséhez "'22. Az nem szorul bővebb bizonyításra, hogy a jogbiz- 
tonságról mondottak és ez a kijelentés enyhén szólva is ellentmondásban áll egymással. A jogsértések kiküszöböléséhez füződő csekélyebb érdek olyan eszközökre vonatkozott, mint például a fedővállalkozások létrehozása, csapda alkalmazása és más hasonló, az alapjogokba súlyos beavatkozást jelentő rendőri müködés. Hozzá kell tenni, hogy az engedélyhez kötést, egyáltalában bármiféle kontroll gyakorlását már az is lehetetlenné tette, hogy a jogalkotó semmiféle konkrét feltételt nem szabott az eszközök túlnyomó többségének a bevetéséhez.

Ilyen körülmények között a demokratikus jogállamokban általában éles kritikával szokták illetni az emberi jogokat és azok érvényesülési garanciáit háttérbe szorító törekvéseket, legalábbis a liberális erők részéről. Magyarországon nem ez történt. Az Országgyülés második legerősebb pártjának, a szabadelvü SZDSZ-nek a vezérszónoka négy pontban jelölte meg a rendőrségi törvény javaslatának vitatható kérdéseit: a rendőrség kormányzati irányítása, a szervezet vezetőinek a kinevezése, az önkormányzatokhoz füződő viszony, a negyedik pedig a rendörség és az állampolgárok viszonya. Kijelentette: „Én azt gondolom, a negyedik az, ahol legközelebb állnak az álláspontok, a vélemények. ${ }^{~}{ }^{23}$ Döntően ezzel magyarázható, hogy a javaslatot egy tartózkodás mellett egyhangúlag megszavazták a képviselők.

A fegyveres szervek hivatásos állományú tagjainak szolgálati viszonyáról szóló törvény

A második parlamenti ciklusban a szocialisták az SZDSZ-szel koalícióban kormányoztak, az utóbbi párt adta a szabályozás szempontjából meghatározó szerepet játszó Belügyminisztérium vezetőjét. Ebben az időszakban fogadták el a fegyveres szervek hivatásos állományú tagjainak szolgálati viszonyáról szóló 1996. évi XLIII. törvényt. A jogszabály alapelvnek tekintette, hogy a rendészeti szervek - így a rendőrség - és a hadsereg belső szervezete és müködése lényegi azonosságot mutat. Ezzel összhangban a jogalkotó megerösítette a rendőrségi törvényben már korábban rögzített feltétlen engedelmességi követelményt, ami alól csak a büncselekmény elkövetésének megtagadása jelentett kivételt. A szabálysértés (akár kisebb értékre elkövetett lopás) már nem szolgálhatott ilyen hivatkozás alapjául. A törvény 69 . §-ának (2) bekezdése kimondta: az említett kivételtől eltekintve , .... a hivatásos állomány tagja a jogszabálysértö parancs, rendelkezés végrehajtását nem tagadhatja meg”. Ez

23 Wekler Ferenc felszólalása az Országgyülés 2003. október 5-i ülésnapján. 
egyenes folytatása annak a gondolatnak, amit a rendőrségről szóló törvényjavaslat vitájában Sóvágó László fogalmazott meg: fontosabb érdek füződik az akár jogellenes működéshez, mint a jogsértések kiküszöböléséhez. A tisztesség kedvéért meg kell jegyezni, hogy a hivatkozott bekezdés azt is kimondta: „a jogszabálysértö parancs, rendelkezés végrehajtásáért kizárólag az azt kiadó felel”. Csakhogy a fegyveres szerveken belül a dolog sajátosságából adódóan tipikusan éppen az a személy gyakorol kontrollt a végrehajtás felett, aki jogosult a parancs, rendelkezés kiadására. A kör bezárult.

Emberi jogi szempontból kiemelést érdemel, hogy a rendöri müködéssel érintett társadalom jogilag alig megragadható, de ténylegesen fennálló emberi jogi veszélyeztetettsége mellett a hivatkozott szabály egy másik - abszolútnak tekinthető - határt is átlépett: a Magyarországon egyébként jogilag sem alulképzett rendőröket nem személyiségnek, hanem lényegében egyszerủen eszköznek minősítette. Ez pedig az emberi méltóság alapjának a megtagadását jelenti. ${ }^{24}$

\section{A polgári repülőgépek lelövéséről}

1983. szeptember 1-jén a szovjet légierő lelőtt egy koreai utasszállító gépet, 269 ember életét kioltva. Az akciót óriási nemzetközi felháborodás kísérte, noha nem volt teljesen egyértelmü a dolog jogi megítélése. ${ }^{25} 2001$. szeptember 11-én terroristák polgári repülőgépeket vezettek az Egyesült Államok fontos létesítményeibe, megölve megközelítőleg háromezer embert. A történtek hatására számos dolgot újraértékeltek Amerikában és a világ más országaiban is. Az egyik válasz a barbár akciókra a repülőgépek lelövésének engedélyezése volt. Magyarországon a honvédelemről és a Magyar Honvédségről szóló 2004. évi CV. törvény 132. §-a tette lehetővé, hogy figyelmeztető vagy megsemmisítő tüzet nyissanak a légterünkben tartózkodó légi jármüre (tehát akár polgári utasszállító repülőgépre is), amennyiben az a fedélzeti fegyverzetét alkalmazza, vagy más módon (más fegyverrel vagy eszközzel) az életés vagyonbiztonságot veszélyeztető súlyos, erőszakos cselekményt követ el, illetve katasztrófát idéz elő, illetőleg egyértelmüen arra lehet következtetni, hogy az $a$ ) vagy a $b$ ) pont szerinti cselekmény elkövetésére törekszik, és a légvédelmi készenléti erők felszólításának szándékosan nem tesz eleget.

\footnotetext{
24 Immanuel Kant: Grundlegung zur Metaphysik der Sitten. Reclam, Stuttgart, 2004, S. 79.

25 Hassan Farooq: A Legal Analysis of the Shooting of Korean Arilines Flight 007 by the Soviet Union. Journal of Air Law and Commerce, vol. 49, no. 3, 1984, pp. 555-588.
} 
Utóbbi esetben a figyelmeztető lövés mellőzhető, ha az eset összes körülményei folytán arra már nincs idő, és a késedelem az élet- és vagyonbiztonság sérelmével járna.

Eltekintve attól a suta - de életveszélyes - fogalmazástól, hogy a légi jármü valamilyen magatartást képes tanúsítani, cselekmény elkövetésére képes törekedni, a dolog lényege az, hogy akár több száz utast szállító polgári repülőgép is lelöhető jogszerüen.

Nem szorul bővebb bizonyításra, hogy a dolog rendkívül súlyos emberi jogi problémákat vet fel. Az sem, hogy (igaz, itt nem a rendőrségről, de a közhatalomról van szó) nem hagyják nyugton a jog szerint cselekvőket. Olyannyira nem, hogy adott esetben megölik azokat az utasokat a személyzettel együtt, akik semmiféle normát nem sértettek.

Németországban a lényegét tekintve ugyanilyen tartalmú rendelkezés törvénybe iktatását heves parlamenti vita előzte meg, a szövetségi elnök pedig - annak ellenére, hogy aláírta - súlyos aggályának adott hangot a tartalmat illetően. Végül a szövetségi Alkotmánybíróság 2006. február 15-én megsemmisítette az alapul szolgáló tényállásban nem érintett emberek elleni fegyverhasználat engedélyezését lehetőségként tartalmazó normát. Érdemes kiemelni, hogy a testület nem kizárólag az élethez való alapjogra hivatkozott, hanem a német jogrend alapját képező, érinthetetlen emberi méltóság degradálására is. Az ítélet kimondta: a felhatalmazás szerinti közhatalmi cselekvés puszta tárgyként, eszközként kezeli az embereket, ezért sérti a német alaptörvénynek az emberi méltóság érinthetetlenségére vonatkozó követelményét. ${ }^{26}$

Rendkívül alapos, körültekintő elemzése alapján Sulyok Gábor is arra a következtetésre jutott, hogy a beavatkozás okának kiváltásában szerepet nem játszó emberek esetleges megsemmisítésével járó légvédelmi akció nem egyeztethető össze az alkotmányosság és a nemzetközi jog alapvető követelményeivel. ${ }^{27}$

Egy vitapartnerem úgy próbálta felesleges és indokolatlan aggályoskodásnak nyilvánítani az általam felvetett problémákat, hogy kijelentette: a dolognak nincs gyakorlati jelentősége, mert a szóba jöhető esetekben az utasok és a személyzet úgyis halálra vannak ítélve az események logikája alapján. Ezzel szemben érdemes megjegyezni, hogy a magyar törvényi szabályozás szerint (a hivatkozott törvény már nem hatályos ugyan, de a helyzet érdemben nem változott) egyáltalán nem feltétel, hogy a légi jármüvön tartózkodó sze-

261 BvR 357/05

27 Sulyok Gábor: A terrorcselekmény elkövetéséhez használt polgári légi jármü lelövésének nemzetközi és alkotmányjogi megítélése. Fundamentum, 2005/3., 30-56. o. 
mélyek józan gondolkodás szerint menthetetlenek legyenek. Sőt, a veszélyeztetett értékek pusztulása sem biztos, hiszen például a 2001-es amerikai támadás során a United Airlines Flight 93 fedélzetén tartózkodó személyek akadályozták meg, hogy a gép elérje célját (nem kizárt, hogy ez éppen a Fehér Ház volt). Saját életüket nem tudták megmenteni, azt feláldozták a hazájukért. Ismertté vált azonban olyan eset is, amikor az utasok és a személyzet leteperte a terroristát, a gép pedig sértetlenül földet ért a rajta tartózkodó emberekkel együtt. $^{28}$

Nem tagadható, hogy a hivatkozott szabályozás mellett is hozhatók érvek, akár az emberi jogokkal összefüggésben. A magyar törvényhozás azonban fel sem vetette a választott megoldás emberi jogi problémáit, nemhogy megválaszolta volna őket. A 2004-es honvédelmi törvény 131-132. §-aihoz füzött indokolás szerint „A fegyverhasználat szabályai megfelelnek a NATO Kiterjesztett Integrált Légvédelmi Rendszere (NATINEADS) kialakitása során a szövetségben elfogadott elveknek, biztositják az ellenséges tevékenységnek minösülö - a fegyverhasználat alapjául szolgáló - cselekmények, helyzetek pontos, a jogállami követelményeknek megfelelö meghatározását". Arról már volt szó, hogy a légi jármü magatartására, sőt: szándékaira alapozó rendelkezések mennyire egyeztethetők össze azzal a tipikus helyzettel, amelyben három csoport: a terroristák, a személyzet és az utasok játszanak a légvédelem számára alig követhetö, akár másodpercenként változó szerepet. A lehetséges következmények azonban csupán annyiban lényegesek a jogalkotó számára, hogy előírta egyes állami vezetők azonnali tájékoztatását. Alapvetően ugyanezt ismétli meg a jelenleg hatályos - és érdemben témánkat érintően ugyanolyan rendelkezéseket tartalmazó - honvédelmi törvény 62 . §-ához füzött indokolás.

A 2004. évi CV. törvény elfogadását megelőző országgyülési vitában az elöterjesztő a terrorizmus elleni harc szükségességének általánosságban való említésén túlmenően fel sem vetette a légi jármüvek - így akár utasszállító polgári repülőgépek - lelövésére adandó felhatalmazás problémáját. ${ }^{29}$

A javaslattal foglalkozó felszólalások ugyancsak teljes mértékben érintetlenül hagyták a légvédelmi rendelkezéseket, pedig volt olyan hozzászóló (Mécs Imre), aki az emberi jogok kérdéséről is értekezett.

Ugyanez mondható el a jelenleg hatályos 2011. évi CXIII. törvényröl, annak előkészítéséről és a javaslat 2011-es parlamenti vitájáról. Vadai Ágnes -

28 https://www.nytimes.com/2009/12/27/us/27plane.html

29 Iváncsik Imre expozéja az Országgyülés 2004. október 4-i ülésnapján. 
aki 2004-ben kormánypárti, 2011-ben ellenzéki képviselő volt - így nyilatkozott: „a Honvédelmi Minisztérium jogászainak és munkatársainak én is szeretném megköszönni, hogy a 2004-es törvény nagy részét abban a formájában, ahogy az ott benne volt, ahogy egyébként egy megállapodás, egy nagy konszenzus része volt, beemelték a honvédelmi törvénybe. Ezzel, azt gondolom, hogy nincs is probléma. ${ }^{{ }^{30}}$ Megjegyzendő, hogy ebbe az átemelt körbe tartozik bele a polgári utasszállító repülőgépek lelövésére (is) adott felhatalmazás.

Mészáros Ádám Zoltán szerint egy ilyen speciális végszükségi esetben a büntetőtörvénynek a jogszabályi engedélyre vonatkozó rendelkezése (24. §) kizárhatja a megsemmisítő tűz alkalmazására adott parancs miatti felelősséget. Ebben teljesen igaza van, de a speciális végszükségi helyzetre való utalás mégis magyarázatra szorul. Arról van szó ugyanis - és itt nyilván a jogi megoldás mögötti elvi álláspont a lényeges -, hogy végszükség esetén is megköveteli a jog a szükségesség és arányosság követelményének a szigorú alkalmazását, ami egyébként, ahogyan arra a hivatkozott szerző utal, ma már az Egyesült Államokban is irányadó. ${ }^{31}$

Ezzel azonban az esetlegesen felvetődő jogi problémák nagy része nincs megoldva. Elég csupán arra utalni, hogy az így megölt emberek hozzátartozói kapnak-e bármiféle kárpótlást, vagy akár csupán segítséget az 1999-es montreali egyezményböl (2005. évi VII. törvény) eredő jogaik érvényesítéséhez (ami nem egyszerü).

A légi járművek - így akár a polgári utasszállító gépek - lelövésével kapcsolatos emberi jogi problémák figyelmen kívül hagyása a szabályozás során jól jelzi a hatalom érzékenységének a teljes hiányát. Amint láttuk: az éppen kormányon lévő erők színezetétől függetlenül.

\section{Újabb tendenciák}

Látszólag az a helyzet, hogy hosszú kihagyás után a közelmúltban elkezdődött az emberi jogok garantálására vonatkozó átgondolt rendszer kiépítése. 2018-ban az alaptörvény módosítása, a magánszféra védelmének az erősítése, valamint a gyülekezési jog újraszabályozása jelzi, hogy a kormány kiemelt figyelmet fordít a jogok helyzetére. Álláspontom szerint azonban nem

30 Vadai Ágnes felszólalása az Országgyülés 2011. június 22-i ülésnapján.

31 Mészáros Ádám Zoltán: Szükség törvényt bont? Az ártatlant sújtó szükségcselekmények a büntetöjogban. Storming Brain Kiadó, Budapest, 2018 
elfogadhatók a jogalkotói szándék mögötti megfontolások. Hogy az alapkérdésre visszatérjek: nem fokozódik a társadalom védelme a totális hatalom felé történő elmozdulással szemben, ellenkezőleg.

Az emberi jogok filozófiai alapjai a mondottak szerint nem túl szilárdak, ezzel szemben a dogmatika határozott fejlödést jelez. A gyakorlatra összpontosító megközelítés - ami az alaptörvény I. cikkének (1) bekezdése alapján elvárható - így viszonylag pontos irányjelzők alapján tud tájékozódni. Természetesen vannak eltérések az egyes országok alkotmánybírósági és más döntései között, az alapkérdésekben azonban nagyfokú egyetértés mutatkozik. Ilyennek tekinthető a jogok elsődlegessége, a törvényhez kötöttség, a szükségesség és arányosság követelménye.

Megítélésem szerint az emberi jogok értelmezésére és alkalmazására vonatkozó, elfogadottnak tekinthető szabályok figyelmen kívül hagyása a törvények megalkotása során nagyobb károkat okozhat, jelentősebb veszélyeket hordoz, mint adott esetben a kodifikáció elmaradása. Mégpedig azért, mert az esetleges joghézagok alkotmánykonform értelmezéssel kitölthetők, az elhibázott kodifikáció azonban eltérítheti a jogalkalmazót a legfontosabb értékekhez való igazodástól.

\section{A véleményszabadság és a gyülekezési jog alaptörvényi értéke}

Hangsúlyozni kell mindenekelött, hogy az alapjogok szabályozásának pontosítása helyeselhető mindaddig, amíg azok alanyi jellegét a tárgyi jog egyéb szempontokat (például közérdek, rendészet stb.) is követő rendelkezései nem rendítik meg. Mind a gyülekezési jognak, mind pedig a véleményszabadság érvényesülésének kiemelkedö jelentősége van egy demokratikus jogállamban. Ezért a hozzájuk kapcsolódó garanciarendszer is kihatással van a társadalom egészének az értékrendjére. Természetesen azt is tudomásul kell venni, hogy egyik említett alapjog sem abszolút. Éppen ezért szükséges a korlátokat is az alkotmányos keretek között világosan rögzíteni.

Az Országgyülés az alaptörvény módosításával megváltoztatta a gyülekezési jog és a véleményszabadság viszonyát a magánszféra védelmére irányuló alapjoghoz. A VI. cikk (1) bekezdése kimondja: „A véleménynyilvánitás szabadsága és a gyülekezési jog gyakorlása nem járhat mások magán-és családi életének, valamint otthonának sérelmével." A módosításra irányuló javaslat indokolása megerősíti azt, ami egyébként a szövegből is kiolvasha- 
tó: az alapvető jogok kollíziója esetén a korlátozhatóság alaptörvényi kereteire és az Alkotmánybíróság gyakorlatára is figyelemmel a magánszféra adott elemeinek a védelme kap fokozott hangsúlyt.

A megszorítások alkotmányos lehetősége azonban egyáltalában nem igényli, hogy éppen a magánszféra védelme kerüljön a gyülekezési jog és a véleményszabadság fölé. Az alkotmánybírósági gyakorlatra, továbbá azzal összefüggésben az amerikai igazságszolgáltatásra való hivatkozás pedig alapvetően téves.

Az Alkotmánybíróság [13/2016. (VII. 18.) AB határozat] valóban kimondta: „mulasztásban megnyilvánuló alaptörvény-ellenes helyzet áll fenn annak következtében, hogy a törvényalkotó nem szabályozta a magánszférához való alapjog és a gyülekezéshez való alapjog kollíziója esetén a kollizió feloldásának szempontjait és annak eljárási kereteit”.

Ebböl egyáltalában nem következik, hogy alaptörvényi szinten kell kimondani: a véleménynyilvánítás szabadsága és a gyülekezési jog gyakorlása nem sértheti a magánélet védelméhez füződő jogokat. Miután a bíróságoknak természetes módon (alaptörvény, 28. cikk) a jogszabályok céljával és az alaptörvénnyel összhangban kell értelmezniük a jogszabályokat, a bevezetett módosítás világos iránymutatást ad az alapjogok rangsorát illetően. Ez viszont nem egyeztethetö össze még a hivatkozott alkotmánybírósági döntéssel sem. Az idézett határozat ugyanis kifejezetten megerösíti a testületnek azon korábbi iránymutatását [30/1992. (V. 26.) AB határozat], amely szerint „,..a gyülekezési jog a kommunikációs alapjogok körébe tartozik [...] Ennek jelentösége pedig abban áll, hogy az Alkotmánybíróság állandó gyakorlata a »kommunikációs alapjogokat" a többi jog fölé helyezi annyiban, hogy »a véleményszabadságot korlátozó törvényeket megszoritóan kell értelmezni«".

Ugyancsak rögzítette az 1992-es, az alaptörvény módosításának indoklásában hivatkozott határozat által nem felülírt döntés: „Történelmi tapasztalat, hogy mindannyiszor, amikor a véleménynyilvánitás szabadságát korlátozták, sérelmet szenvedett a társadalmi igazságosság, az emberi kreativitás, csökkent az emberben rejlö képességek kibontakozásának lehetösége. A káros következmények nem csupán az individuum, hanem a társadalom életében is megmutatkoztak és az emberiség fejlödésének sok szenvedéssel járó zsákutcájához vezettek. Az eszmék, nézetek szabad kifejtése, a mégoly népszerütten vagy sajátos elképzelések szabad megnyilvánulása a fejlödni- képes és valóban eleven társadalom létezésének alapfeltétele."

A módosítási javaslat indokolása tehát félrevezető: az abban felhívott alkotmánybírósági határozat egyáltalában nem alapozta meg az alapjogok ér- 
tékrendjének a megváltoztatását. Maga a testület egyébként a jogalkotó által eltorzítva értelmezett 13/2016. (VII. 18.) AB határozathoz hasonlóan még 2018-ban is egyetértően és indokaival együtt idézte a 30/1992. (V. 26.) AB határozatot [3145/2018. (V. 7.) AB határozat].

Világosan ki kell mondani: az Alkotmánybíróság anyagi jogi értelemben vett sorrendet állított fel az alapjogok között. Ennek megfelelően a véleményszabadság és a hozzá közvetlenül kapcsolódó jogok - így a gyülekezési is - az élethez és az emberi méltósághoz való jog alatt, de a többi fölött helyezkednek el. ${ }^{32}$

Nyilvánvalóan ezért döntött úgy a jogalkotó, hogy az alaptörvényben rögzíti a véleményszabadság, a gyülekezési jog, illetve a magánélet védelméhez füződő jogok új viszonyát. Ezzel felborította a hivatkozott fontossági és korlátozhatósági rangsort. Méghozzá úgy, hogy elvi megokolást nem adott. Az eredeti hierarchia világos érvelésen nyugodott, ami egyébként a nemzetközi szerződésekkel és más alkotmányos demokráciák szabályozásával is összhangban állt, gondoljunk csak az Egyesült Államok alkotmánykiegészítéseire.

Megjegyzendö, hogy az indokolás által kiemelt két amerikai ítélet sem szolgál alapul a demokrácia alapértékeit és a magánéletet oltalmazó normák közötti hierarchikus viszony megváltoztatására. A Carey v. Brown-ügyben [447 U.S. 455 (1980)] a Legfelsőbb Bíróság történetesen éppen azt mondta ki, hogy alkotmánysértő az az Illinois állambeli jogszabály, amely megtiltja a lakóhelyek előtti, őrködés jellegü demonstrációkat (picketing). A másik ítélet [Frisby v. Schultz, 487 U.S. 474 (1988)] is legfeljebb látszólag visz közelebb a kormány által javasolt és az Országgyülés által elfogadott rendezéshez. Az ugyanis a másikkal szemben a hasonló tartalmú tiltást nem nyilvánította alkotmánysértőnek. Hangsúlyozta ugyanakkor, hogy a magánéletbe nem elviselhetetlen módon beavatkozó, a lakókat nem „foglyul ejto”” (bár természetesen a picketing eredeti jelentésével [sztrájkőrség] ellentétben ténylegesen sem az Egyesült Államokban, sem Magyarországon nincs jogi lehetőség a lakók ki- és bemenetelének az akadályozására) demonstrációkra továbbra is van lehetöség.

A gyülekezési jog - és a véleményszabadság - tényleges, a Hannah Arendt által megjelölt irányba mutató korlátozása azért valósult meg, mert a törvényhozó a magánszféra védelmének az előbbiek rovására történő kiterjesztésével egyértelműen demokráciaellenes irányt szabott a jogalkalmazás számára.

32 Sólyom László: Normahierarchia az Alkotmányban. Akadémiai székfoglaló. Magyar Tudományos Akadémia, Budapest, 2014, 8. o. 
Ehhez kapcsolódik az igen széles mérlegelési jogot adó rendőrségi hatáskörök biztosítása. Ráadásul úgy, hogy a testületnek adott iránymutatások sem kínálnak világos kereteket a mérlegeléshez. Még a kormány politikájához is nehezen igazítható az alaptörvényi változtatás érvényesítésének a gyakorlatba történő átültetése. Hazánk miniszterelnöke ugyanis - valóban a következetesen hangoztatott tételeknek megfelelően - a közszolgálat leendő tagjai számára kijelentette: „A szemünk elött tehát egy olyan állam képe lebeg, amely erös, méltányos és tisztelhetö, mert minden szegletében a közérdeket rendeli a magánérdek elé. " ${ }^{33}$ A gyülekezési jog és a véleményszabadság gyakorlása a mondottak szerint elsőrendü közérdek, a magánszféra háborítatlansága pedig közvetlenül magánérdek, legfeljebb áttételesen közösségi érték.

Hangsúlyozni kell, hogy a kommunikációs jogok - mint a közérdekhez közel álló értékek - preferálása a magánszféra zavartalanságával szemben korábban megszilárdult a jogalkalmazási gyakorlatban is. Példa erre az említett - kiemelt - körbe sorolt vallásszabadság körébe sorolt harangozásnak az emberek nyugodt pihenése iránti igénnyel és a környezet károsításának a megakadályozását szolgáló rendészeti normákkal szemben történő előnyben részesítése (Kúria, 1737/2007. sz. közigazgatási elvi határozat).

A rendőrség diszkrecionális hatalmának a bővítését egyértelmüen jelzi az új gyülekezési törvény (2018. évi LV. törvény) 13. §-ának (1) bekezdése. Ennek alapján a gyülésnek a bejelentett helyszínen vagy időpontban történő megtartása megtiltható, ha a közbiztonság vagy a közrend közvetlen, szükségtelen és aránytalan veszélyeztetésére, illetőleg a mások jogait és szabadságát érintő szükségtelen mértékủ és aránytalan sérelmére lehet következtetni, és ezen értékek védelme egyéb korlátozással nem biztosítható. A jogkör azért diszkrecionális, mert - ellentétben a mintaként használt német szabályozással - a közbiztonság és a közrend hazánkban határozatlan jogfogalmak, a törvény is csupán példákat sorol fel a hozzájuk köthető értékekről. Az általános indokolás szerint a két kifejezés nem idegen a magyar jogtól, egyebek mellett a rendőrségről szóló törvény is használja. Ez kétségtelenül igaz, de nem változtat azon a tényen, hogy az oltalmazásukra hivatott rendőrök nem tudnák definiálni - a jogalkalmazástól elvárt egységes tartalommal egészen biztosan nem - az említett jogi tárgyakat.

Ilyen körülmények között az irányítás eszközei kerülnek elötérbe, különös tekintettel arra a máig élő szabályra, amely szerint a rendőr a jogszabálysér-

33 Interjú Orbán Viktor miniszterelnökkel. Bonum Publicum, 2017. február, 8. o. 
tő utasítás teljesítését nem tagadhatja meg [1994. évi XXXIV. törvény, 12. § (2) bekezdés].

A jelzett viszonyok egyébként a bírósági felülvizsgálat garanciális értékét is relativizálják, hiszen az igazságszolgáltatás a döntések törvényességét vizsgálja, de a mérlegelési jogot csak szélsőséges esetben érintheti. A fogalmak tisztázatlansága, továbbá a konkrét körülmények ismeretének a hiánya miatt a bírák korrekciós lehetősége rendkívül korlátozott. 